\title{
Briquette Smelting in Electric Arc Furnace to Recycle Wastes from Stainless Steel Production
}

\author{
Qi-xing YANG ${ }^{1}, \quad$ An-jun $\mathrm{XU}^{2}$, Peng XUE², Dong-feng $\mathrm{HE}^{2}$, Jian-li $\mathrm{LI}^{3}$, Bo BJÖRKMAN ${ }^{1}$ \\ (1. Minerals and Metallurgical Research Laboratory (MiMeR), Luleå University of Technology, Luleå SE-971 87, Sweden; \\ 2. Department of Ferrous Metallurgy, School of Metallurgical and Ecological Engineering, University of Science and \\ Technology Beijing, Beijing 100083, China; 3. The State Key Laboratory of Refractories and Metallurgy, Wuhan \\ University of Science and Technology, Wuhan 430081, Hubei, China)
}

\begin{abstract}
Wastes from stainless steel production were briquetted together with carbon for smelt-reduction in the electric arc furnace, EAF, to achieve an internal recycling. A laboratory induction furnace was used to simulate the EAF. With a close simulation of the smelting, disintegration of the briquettes heated under load and recovery of metals from briquettes melted together with stainless steel and slag former were investigated. The influences of test conditions on carbon reduction of oxides in the briquettes were also examined. The briquettes endured heating at $1186^{\circ} \mathrm{C}$ under load of $3.5 \mathrm{~kg}$ and could be charged to the melt in small quantity without causing serious splashing. For a high metal recovery, it was necessary to charge the briquettes together with slag former. Small local zones of smelt-reduction with high carbon concentration could thus be formed during the charger heating. Silicon content in the metal near to the briquettes should be minimised to achieve a high degree of carbon reduction. Based on results obtained from this study, suggestions were made on smooth operations of smelt-reduction of the briquettes by using EAF or induction furnace with large scales.
\end{abstract}

Key words: briquette; stainless steel; smelting; reduction; waste; recycling; carbon; silicon; EAF

Wastes from the production of stainless steel could be recycled in the steel plant by using the electric arc furnace, EAF, during the operation of scrap melting ${ }^{[1]}$. This method of internal recycling can be considered more beneficial to both environment and economy, as it is then possible to save energy needed to re-melt metal products from the recycling and to transport the wastes and products. For a smooth recycling operation, an agglomeration is generally performed to make briquettes or pellets for charging and smelting the waste in $\mathrm{EAF}^{[2,3]}$.

Some of the present authors have conducted plant trials of the internal recycling, via smelting of waste briquettes of 3-6 tonnes in an EAF producing crude stainless steel melt of 85 tonnes $^{[4]}$. There were no negative effects found on the quality of the crude stainless steel tapped from the trail heats. Reduction mechanisms for $\mathrm{Ni}$, $\mathrm{Cr}$ and $\mathrm{Fe}$ oxides in the briquettes were discussed based on some of the results from the trials, as well as effects of solid state $\mathrm{C}-\mathrm{O}$ reactions on recovery of metal elements from other materials charged in the EAF.

In the present study, an induction furnace was used to simulate EAF smelting of the same briquettes used in the plant trials of the internal recycling ${ }^{[4]}$. The size degradation of briquettes was examined during heating. Different methods were used to charge and melt the briquettes together with metal materials and slag former, in order to examine influences of operation conditions on rates of metal recovery and utilisation of reducing agents.
Some of the results achieved from this study may be helpful for evaluations of results from the plant trials ${ }^{[4]}$. The results may also be referred to for a smooth operation of the smelt-reduction of wastes in either an EAF or an induction furnace of large scales.

\section{Experimental}

\subsection{Equipment and materials for tests of briquette smelting}

Fig. 1 shows the set-up for some of the tests. The coil assembly (1) of the induction furnace was connected to a power generator of maximum $60 \mathrm{~kW}$ and 3 $\mathrm{kHz}$. A crucible (2) was placed in the assembly to contain charging materials for heating and smelting. The crucibles were made by refractory castable containing $80 \% \mathrm{MgO}$, reinforced with steel fibres. The inner and outer diameter, the outer height and the thickness of the crucible bottom were 136, 192, 380 and $40 \mathrm{~mm}$, respectively.

A graphite tube (ㅁ) with the height and inner and outer diameter of 220, 60 and $130 \mathrm{~mm}$, respectively, acted as a heating element in tests of A-series. The upper, outer part of the tube was covered by refractory castable for protection. The lower part of the tube, inserted in the crucible for about $130 \mathrm{~mm}$, could use the induction power to reach $1400{ }^{\circ} \mathrm{C}$ during a test with a melt temperature 


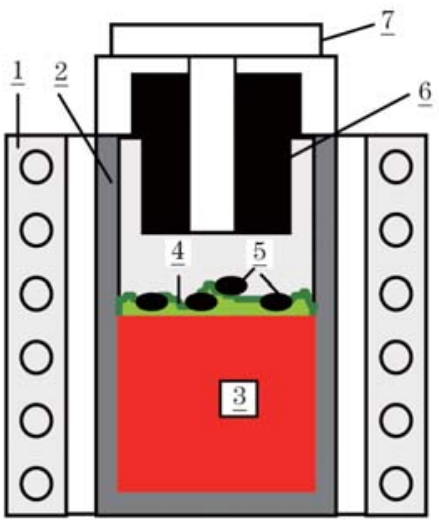

1-Induction coil; 2-Crucible (MgO 80\%); 3-Steel bath; 4-Slag;

5-Briquettes; 6-Graphite tube; 7-Refractory cover.

Fig. 1 Set-up for some of the tests

around $1550{ }^{\circ} \mathrm{C}$. By the tube heating of the upper wall of the crucible and the slag zone, quantities of the splashed slag and metal solidified on the wall were largely reduced. Temperature measurements and melt sampling were performed through the central hole of the tube. Before the charge melting and during the time there was no sampling or other operations the crucible was closed by a refractory cover ( $\underline{7})$.

Two types of the briquettes, A and B, with composition data presented in Tables 1 and 2, were produced by a commercial briquetting machine, using wastes from stainless steel plants mixed together with lime and coke breeze. The carbon in the briquettes was from two sources, the molasses added as binder and coke breeze. The briquettes have a shape similar to an almond with length, width and height of 60,45 and $30 \mathrm{~mm}$, respectively. In average, a briquette of type A and type B weighed, respectively, $85 \mathrm{~g}$ and $75 \mathrm{~g}$.

Table 1 Material compositions in briquettes of types A and B

\begin{tabular}{ccc} 
& & mass $\%$ \\
\hline Briquette & Type A & Type B \\
\hline Oily mill sludge & 45.0 & 45.0 \\
Scale from annealing & 13.5 & 9.0 \\
Grinding swarf & 18.0 & 13.5 \\
Lime & 10.0 & 10.0 \\
Coke breeze & 13.5 & 22.5 \\
\hline
\end{tabular}

The slag former of type A was similar in composition to the slag produced at the end of meltdown of the stainless steel scrap by the EAF, Table 2. The type B was obtained by adding $40 \%$ dolomite lime to type A, giving a higher basicity. Pieces and ingot parts of stainless steel scrap were used as the metal charge of basic type, low in both carbon and silicon. Ferroalloys and pieces and ingot parts of low-carbon iron were mixed together with the basic metal to adjust the carbon and silicon contents. The materials used and calculated compositions of the charged metal are shown in Table 3.

Table 2 Chemical compositions of the briquettes and

\begin{tabular}{|c|c|c|c|c|}
\hline & & former & & $\operatorname{mass} \%$ \\
\hline \multirow{2}{*}{ Composition } & \multicolumn{2}{|c|}{ Briquette } & \multicolumn{2}{|c|}{ Slag former } \\
\hline & Type A & Type B & Type A & Type B \\
\hline $\mathrm{C}$ & 17.44 & 24.38 & 0.02 & 0.06 \\
\hline $\mathrm{Fe}_{2} \mathrm{O}_{3}$ & 36.44 & 36.12 & 0.57 & 0.49 \\
\hline $\mathrm{CaO}$ & 22.22 & 18.86 & 41.95 & 45.10 \\
\hline $\mathrm{Cr}_{2} \mathrm{O}_{3}$ & 8.13 & 7.04 & 3.27 & 2.01 \\
\hline $\mathrm{MgO}$ & 5.30 & 4.07 & 8.60 & 24.45 \\
\hline $\mathrm{SiO}_{2}$ & 3.46 & 2.21 & 34.79 & 21.18 \\
\hline $\mathrm{NiO}$ & 2.89 & 2.73 & 0.06 & 0.04 \\
\hline S & 0.30 & 0.41 & 0.09 & 0.06 \\
\hline $\mathrm{Al}_{2} \mathrm{O}_{3}$ & 1.58 & 1.77 & 3.99 & 2.56 \\
\hline $\mathrm{MnO}$ & 0.78 & 0.73 & 3.79 & 2.31 \\
\hline $\mathrm{MoO}_{3}$ & 0.24 & 0.19 & & \\
\hline $\mathrm{TiO}_{2}$ & 0.16 & 0.12 & 2.23 & 1.34 \\
\hline $\mathrm{CaO} / \mathrm{SiO}_{2}$ & 6.42 & 8.53 & 1.21 & 2.13 \\
\hline
\end{tabular}

\subsection{Test operations and observations}

One type of the operations, performed in test P1, was to melt the metal and briquettes together without adding any slag former. About $73 \%$ of the type A briquettes, $60 \%$ of the stainless steel scrap and iron pieces were charged before heating, as well as $64 \%$ of the Sicontaining alloy. The remaining charges were added after melting of the initial charge. The later charged briquettes floated on the surface causing a weak melt boiling. Some parts of the briquettes were found adhering to the crucible wall under the melt surface after tapping. These briquette parts may have sintered together with the refractory during heating. The sintered parts were sampled for analysing their contents of carbon and metal oxides.

Another operation type, used in tests P4 and P5, was to first melt the metal and slag former and, then, to charge the briquettes for smelting. Argon gas with flow rate of 10 $\mathrm{L} / \mathrm{min}$ was blown in the crucible for most of the time during the two tests to prevent melt-air contact. The quantities of briquettes charged each time in test P5 were nearly $2 \%$ of the metal mass, which were larger than these in test P4. Thus the melt boiling induced by the briquette additions in test P5 was much stronger than that in P4. As a result, slag of 627 gram was found solidified on the crucible upper wall after test P5. Un-melted briquettes were not found after melt tapping in the two tests, indicating a total dissolution of the briquettes in the slag.

For the tests of A-series, A-2, A-6 and A-10, all of 
Briquette Smelting in Electric Arc Furnace to Recycle Wastes from Stainless Steel Production

Table 3 Some of the materials used in the tests and analysis of metal charges

\begin{tabular}{|c|c|c|c|c|c|c|c|c|}
\hline \multicolumn{3}{|c|}{ Test code } & $\mathrm{P} 1$ & $\mathrm{P} 4$ & P5 & A-2 & A-6 & A-10 \\
\hline \multirow{2}{*}{ Briquette } & \multicolumn{2}{|c|}{ Type } & A & A & A & A & A & B \\
\hline & \multicolumn{2}{|c|}{ Mass $/ \mathrm{kg}$} & 1.0 & 1.0 & 1.0 & 0.60 & 1.8 & 0.90 \\
\hline \multirow{2}{*}{ Slag former } & \multicolumn{2}{|c|}{ Type } & & $\mathrm{A}$ & $\mathrm{A}$ & B & B & $\mathrm{B}$ \\
\hline & \multicolumn{2}{|c|}{ Mass/kg } & & 0.60 & 1.00 & 0.72 & 0.72 & 0.72 \\
\hline \multirow{10}{*}{ Metal charge } & \multicolumn{2}{|c|}{ Mass $/ \mathrm{kg}$} & 20.0 & 20.0 & 20.0 & 12.0 & 12.0 & 12.0 \\
\hline & \multirow{9}{*}{$\begin{array}{l}\text { Composition/ } \\
\text { mass } \%\end{array}$} & $\mathrm{C}$ & 1.50 & 0.50 & 1.50 & 1.49 & 1.49 & 0.03 \\
\hline & & $\mathrm{Si}$ & 0.87 & 0.41 & 0.87 & 0.99 & 1.04 & 0.31 \\
\hline & & $\mathrm{Mn}$ & 0.59 & 1.20 & 1.20 & 1.18 & 1.19 & 1.31 \\
\hline & & $\mathrm{P}$ & 0.02 & 0.02 & 0.02 & 0.02 & 0.02 & 0.03 \\
\hline & & S & 0.01 & 0.01 & 0.01 & 0.02 & 0.02 & 0.01 \\
\hline & & $\mathrm{Cr}$ & 18.01 & 17.99 & 18.0 & 17.59 & 17.62 & 17.67 \\
\hline & & $\mathrm{Ni}$ & 9.01 & 9.00 & 9.00 & 9.46 & 9.38 & 9.31 \\
\hline & & Mo & 0.11 & 0.25 & 0.11 & 0.10 & 0.11 & 0.32 \\
\hline & & $\mathrm{Fe}$ & 69.42 & 69.91 & 68.83 & 68.75 & 68.78 & 70.29 \\
\hline
\end{tabular}

the test materials were charged at room temperature. In general, at the crucible bottom there was a layer of metal pieces, above which there was a layer of the briquettes mixed with slag former. For test A-6 with the largest briquette mass, there were three briquette layers each separated by a metal layer. The lowest briquette layer for both test A-2 and A- 6 was sandwiched by layers of metal high in silicon content, facilitating close contacts of oxides in the briquettes with both silicon and carbon.

Heating of 6 extra briquettes of types A and B was carried out during tests A-2 and A-10, respectively, with some of the operation data seen in Table 4. There was an ingot part weighing about $3.5 \mathrm{~kg}$ placed on the heated briquettes. The ingot part was lifted to allow taking one or two heated briquettes out of the crucible. The briquettes out of the crucible were cooled in $\mathrm{N}_{2}$ atmosphere for later examinations. Disintegration under the load occurred for briquettes of type B at $1328^{\circ} \mathrm{C}$. Below $1186^{\circ} \mathrm{C}$, there was no disintegration observed for any types of the briquettes, Table 4. Melting tests continued after all the 6 briquettes were taken out from the crucible. A moderate melt boiling was observed near the end of the charge melting.

Table 4 Data of heating briquettes of types A and B in test A-2 and A-10

\begin{tabular}{cccccc}
\hline $\begin{array}{c}\text { Time in test A-2/ } \\
\text { min }\end{array}$ & $\begin{array}{c}\text { Temperature of } \\
\text { briquettes } /{ }^{\circ} \mathrm{C}\end{array}$ & $\begin{array}{c}\text { Briquettes of type A tak- } \\
\text { ing out }\end{array}$ & $\begin{array}{c}\text { Time in test A-10/ } \\
\text { min }\end{array}$ & $\begin{array}{c}\text { Temperature of } \\
\text { briquettes } /{ }^{\circ} \mathrm{C}\end{array}$ & $\begin{array}{c}\text { Briquettes of type B tak- } \\
\text { ing out }\end{array}$ \\
\hline 30 & 639 & 1 & 30 & 915 & 1 \\
60 & 775 & 1 & 60 & 923 & 1 \\
90 & 940 & 1 & 90 & 1180 & 1 \\
100 & 1150 & 1 & 100 & 1328 & Small parts $^{1)}$ \\
108 & 1186 & 2 & & & \\
\hline
\end{tabular}

Note: 1) Only small parts of the disintegrated briquettes were taken out of the crucible.

In all the tests, except for P1 and P5, fluorspar with $95 \%$ of $\mathrm{CaF}_{2}$ and weighing totally $42-60 \mathrm{~g}$ was added. For the A-series tests, $\mathrm{FeSi}$ with $74.6 \%$ of $\mathrm{Si}$ was added to the melt 10-20 min before tapping for a further reduction of metal oxides in the slag. After melt tapping, there was a flushing of $\mathrm{N}_{2}$ or Ar gas of $10 \mathrm{~L} /$ min to protect any test remains in the crucible, except in test P1. It could be mentioned that there were always some percentages of the final slag that had disintegrated into white powder, when slag former of type B was used. The slag and metal obtained from tests were carefully weighed to acquire the mass data for recovery and reduction calculations.

\section{Results and Discussion}

Mass increase of $\mathrm{Cr}$ in the metal was calculated by using metal mass and analyses given in Tables 3 and 5 in the equation below:

Mass increase of $\mathrm{Cr}=(\mathrm{Cr}$ mass in obtained metal$\mathrm{Cr}$ mass in charged metal)/Cr mass in charged metal $\times 100 \%$

Mass increases of $\mathrm{Ni}, \mathrm{Fe}$ and the metal obtained were computed by using the same method. The data of mass increase are presented in the lower part of Fig. 2 as important indexes for metal recovery from the briquettes. 
Briquette Smelting in Electric Arc Furnace to Recycle Wastes from Stainless Steel Production

Table 5 Data of test operation, analyses of tapped metal and results of Si recovery

\begin{tabular}{|c|c|c|c|c|c|c|c|c|}
\hline \multicolumn{3}{|c|}{ Test No. } & $\mathrm{P} 1$ & P4 & P5 & A-2 & A- 6 & A-10 \\
\hline \multirow{2}{*}{ FeSi added } & \multicolumn{2}{|c|}{ Charging time/min } & & & & 147 & 73 & 149 \\
\hline & \multicolumn{2}{|c|}{ Mass/kg } & & & & 0.096 & 0.072 & 0.024 \\
\hline \multirow{2}{*}{ Melt tapping } & \multicolumn{2}{|c|}{ Tapping time/min } & 85 & 105 & 100 & 171 & 88 & 164 \\
\hline & \multicolumn{2}{|c|}{ Temperature $/{ }^{\circ} \mathrm{C}$} & 1659 & 1570 & 1554 & 1562 & 1644 & 1628 \\
\hline \multirow{10}{*}{ Metal obtained } & \multicolumn{2}{|c|}{ Mass/kg } & 20.179 & 20.332 & 20.135 & 12.255 & 12.76 & 12.408 \\
\hline & \multirow{9}{*}{$\begin{array}{c}\text { Composition/ } \\
\text { mass } \%\end{array}$} & $\mathrm{C}$ & 1.65 & 0.83 & 1.68 & 1.84 & 2.47 & 0.99 \\
\hline & & $\mathrm{Si}$ & 0.74 & 0.24 & 0.46 & 0.93 & 1.05 & 0.29 \\
\hline & & $\mathrm{Mn}$ & 0.64 & 1.33 & 1.30 & 1.36 & 1.16 & 1.45 \\
\hline & & $\mathrm{P}$ & 0.02 & 0.03 & 0.02 & 0.02 & 0.03 & 0.03 \\
\hline & & $S$ & 0.010 & 0.010 & 0.010 & 0.003 & 0.001 & 0.004 \\
\hline & & $\mathrm{Cr}$ & 17.97 & 17.92 & 18.08 & 17.49 & 16.84 & 17.50 \\
\hline & & $\mathrm{Ni}$ & 8.95 & 8.84 & 8.94 & 9.39 & 9.44 & 9.19 \\
\hline & & Mo & 0.14 & 0.29 & 0.15 & 0.14 & 0.20 & 0.35 \\
\hline & & $\mathrm{Fe}$ & 69.54 & 70.01 & 69.06 & 68.45 & 68.40 & 69.48 \\
\hline \multicolumn{3}{|c|}{ Si lost before adding FeSi/kg } & 0.025 & 0.031 & 0.081 & 0.073 & 0.046 & 0.017 \\
\hline \multicolumn{3}{|c|}{ Si recovery from $\mathrm{FeSi}$ added $/ \%$} & & & & 90.3 & 98.2 & 86.6 \\
\hline
\end{tabular}

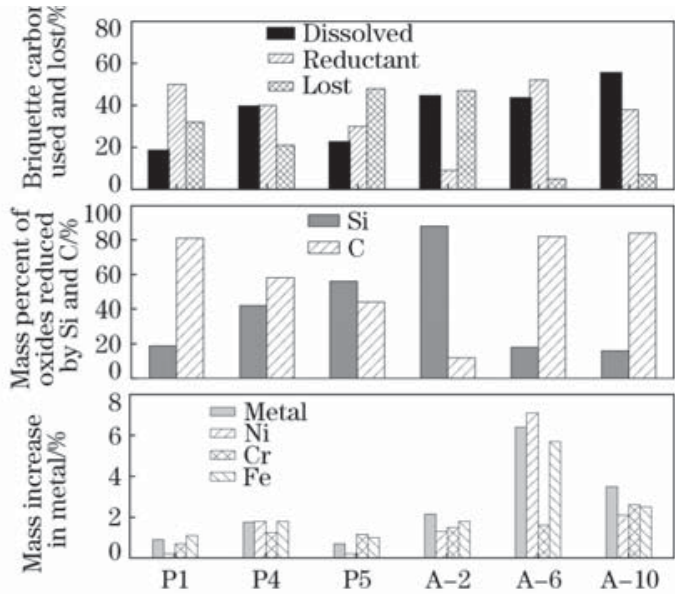

Fig. 2 Increases of element mass in metal and reductant utilisation for the tests
Similarly, oxide contents in the final slag, presented in Tables $6-8$, can also be used to estimate the recovery. The recoveries of $\mathrm{Si}$ from the FeSi added are shown in Table 5 for the tests of A-series. Higher recovery rates of the metals from the briquettes achieved before the $\mathrm{FeSi}$ addition led, generally, to higher values of the Si-recoveries.

The loss of Si before adding FeSi in Table 5 was assumed due, entirely, to the Si-reduction of the oxides in the briquettes and slag former. The oxides left after the Si-reduction were reduced by the briquette carbon. Percentages of oxides reduced by $\mathrm{Si}$ and $\mathrm{C}$ and percentages of the carbon in briquettes used and lost were then calculated with values presented in the middle and upper parts of Fig. 2, respectively.

Table 6 Oxide contents in slag samples and un-melted briquette parts

$\operatorname{mass} \%$

\begin{tabular}{|c|c|c|c|c|c|c|c|c|c|}
\hline \multirow{3}{*}{ Oxide } & \multirow{3}{*}{$\begin{array}{l}\text { In parts of briquette remained } \\
\text { on wall from P1 }\end{array}$} & \multicolumn{8}{|c|}{ Contents of oxides in slag samples from the tests } \\
\hline & & \multirow{2}{*}{$\begin{array}{c}\mathrm{P} 1 \\
\text { Final }\end{array}$} & \multicolumn{4}{|c|}{$\mathrm{P} 4$} & \multicolumn{2}{|c|}{ P5 } & \multirow{2}{*}{$\begin{array}{c}\text { A-6 } \\
\text { Final }\end{array}$} \\
\hline & & & At $58 \mathrm{~min}$ & At $90 \mathrm{~min}$ & Final & On wall & Final & On wall & \\
\hline $\mathrm{FeO}$ & 5.8 & 0.95 & 0.40 & 4.10 & 1.50 & 2.50 & 0.50 & 2.20 & 0.81 \\
\hline $\mathrm{Cr}_{2} \mathrm{O}_{3}$ & 4.5 & 1.03 & 1.30 & 1.80 & 2.20 & 2.20 & 0.60 & 1.40 & 0.51 \\
\hline $\mathrm{NiO}$ & 0.81 & 0.09 & 0.04 & 0.20 & 0.09 & 0.16 & 0.05 & 0.16 & 0.03 \\
\hline $\mathrm{MnO}$ & 0.37 & 0.34 & 2.80 & 1.70 & 2.70 & 1.90 & 1.60 & 1.20 & 0.20 \\
\hline
\end{tabular}

Table 7 Data of operations and sampling of metal and slag during tests A-2

\begin{tabular}{|c|c|c|c|c|c|c|c|c|c|c|c|c|}
\hline \multirow{2}{*}{ Time/min } & \multirow{2}{*}{ Temperature $/{ }^{\circ} \mathrm{C}$} & \multirow{2}{*}{ Operation } & \multicolumn{5}{|c|}{ Element in metal sample/mass\% } & \multicolumn{5}{|c|}{ Oxide in slag sample/mass\% } \\
\hline & & & $\mathrm{C}$ & $\mathrm{Si}$ & $\mathrm{Mn}$ & $\mathrm{Cr}$ & $\mathrm{Ni}$ & $\mathrm{CaO}$ & $\mathrm{SiO}_{2}$ & $\mathrm{MnO}$ & $\mathrm{FeO}$ & $\mathrm{Cr}_{2} \mathrm{O}_{3}$ \\
\hline 0 & & Starting & 1.49 & 1.00 & 1.18 & 17.59 & 9.46 & 45.1 & 21.2 & 2.3 & 0.56 & 2.01 \\
\hline 135 & 1568 & Sampling & 1.77 & 0.39 & 1.34 & 17.61 & 9.46 & 38.7 & 26.8 & 1.1 & 2.60 & 0.80 \\
\hline 143 & & Sampling & 1.78 & 0.38 & 1.35 & 17.61 & 9.51 & 37.9 & 27.1 & 1.0 & 2.00 & 0.70 \\
\hline 147 & & Add FeSi & & & & & & & & & & \\
\hline 165 & 1562 & Sampling & 1.90 & 0.95 & 1.36 & 17.47 & 9.40 & 37.1 & 26.8 & 1.0 & 3.40 & 0.90 \\
\hline 167 & & Sampling & 1.84 & 0.93 & 1.36 & 17.49 & 9.39 & 36.2 & 26.8 & 0.8 & 2.90 & 0.70 \\
\hline
\end{tabular}


Briquette Smelting in Electric Arc Furnace to Recycle Wastes from Stainless Steel Production

Table 8 Data of operations and sampling of metal and slag during tests A-10

\begin{tabular}{|c|c|c|c|c|c|c|c|c|c|c|c|c|}
\hline \multirow{2}{*}{ Time/min } & \multirow{2}{*}{ Temperature $/{ }^{\circ} \mathrm{C}$} & \multirow{2}{*}{ Operation } & \multicolumn{5}{|c|}{ Element in metal sample/mass $\%$} & \multicolumn{5}{|c|}{ Oxide in slag sample/mass $\%$} \\
\hline & & & $\mathrm{C}$ & $\mathrm{Si}$ & $\mathrm{Mn}$ & $\mathrm{Cr}$ & $\mathrm{Ni}$ & $\mathrm{CaO}$ & $\mathrm{SiO}_{2}$ & $\mathrm{MnO}$ & $\mathrm{FeO}$ & $\mathrm{Cr}_{2} \mathrm{O}_{3}$ \\
\hline 0 & & Starting & 0.03 & 0.31 & 1.30 & 17.67 & 9.31 & 45.1 & 21.2 & 2.3 & 0.56 & 2.01 \\
\hline 130 & 1700 & Sampling & 0.95 & 0.19 & 1.46 & 17.58 & 9.22 & 42.0 & 23.3 & 0.9 & 3.1 & 1.80 \\
\hline 140 & 1618 & Sampling & & & & & & 44.3 & 23.8 & 0.6 & 1.5 & 0.90 \\
\hline 143 & 1623 & Sampling & 0.96 & 0.16 & 1.46 & 17.62 & 9.22 & & & & & \\
\hline 148 & & Sampling & & & & & & 41.0 & 22.8 & 0.7 & 3.3 & 1.10 \\
\hline 149 & 1645 & Add FeSi & & & & & & & & & & \\
\hline 159 & 1628 & Sampling & 0.99 & 0.29 & 1.45 & 17.50 & 9.19 & 37.3 & 20.7 & 0.6 & 2.4 & 0.90 \\
\hline
\end{tabular}

\subsection{Influences of charging and melting methods on} recoveries and carbon reduction

Changes of metal temperature and compositions against time during test $\mathrm{P} 1$ are plotted in Fig. 3. The metal $[\mathrm{Cr}]$, chromium concentration in mass percent, increased by about $0.1 \%$ from 80 to $83 \mathrm{~min}$, with both metal $[\mathrm{Mn}]$ and $[\mathrm{Si}]$ increasing by $0.01 \%$. There were $\mathrm{Cr}_{2} \mathrm{O}_{3}$ of $4.5 \%$ and $\mathrm{MnO}$ of $0.37 \%$ existing in the unmelted briquette parts (Table 6). These data suggest that the first step for the observed recovery of $\mathrm{Mn}$ and $\mathrm{Cr}$ is the reaction between the carbon and the oxides in the unmelted briquettes.

At the beginning, the rate of the reaction may be limited by heat transfer between the liquid metal and solid

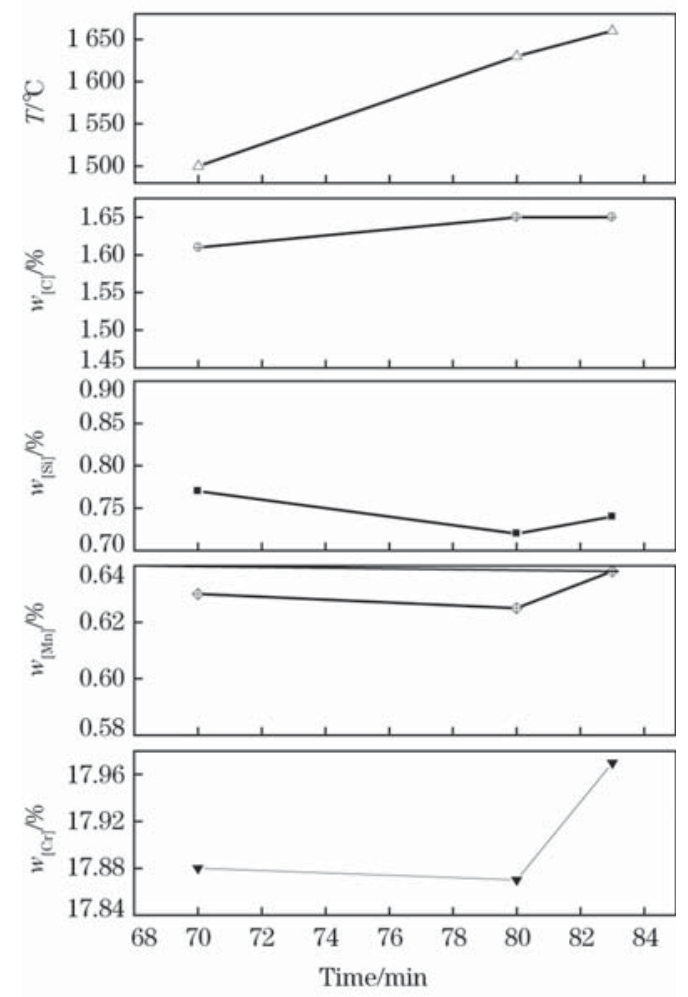

Fig. 3 Changes of metal temperature and compositions during test P1 briquettes under the condition of lower temperature. Due to increases of the contact time and melt temperature from 1634 to $1659{ }^{\circ} \mathrm{C}$ (Fig. 3), the temperature inside briquettes may be increased to accelerate the carbon reduction. Some of the reducible oxides and carbon were left in the un-melted briquettes, Table 6, resulting in a lower recovery of the metals in test P1 than in tests P4 and A-2 as shown in Fig. 2. These results demonstrate that for the oxide reduction to complete, it is necessary to either increase the contact time and metal temperature or use some flux for the briquettes.

Fig. 4 shows the effect of the flux on briquette melting.

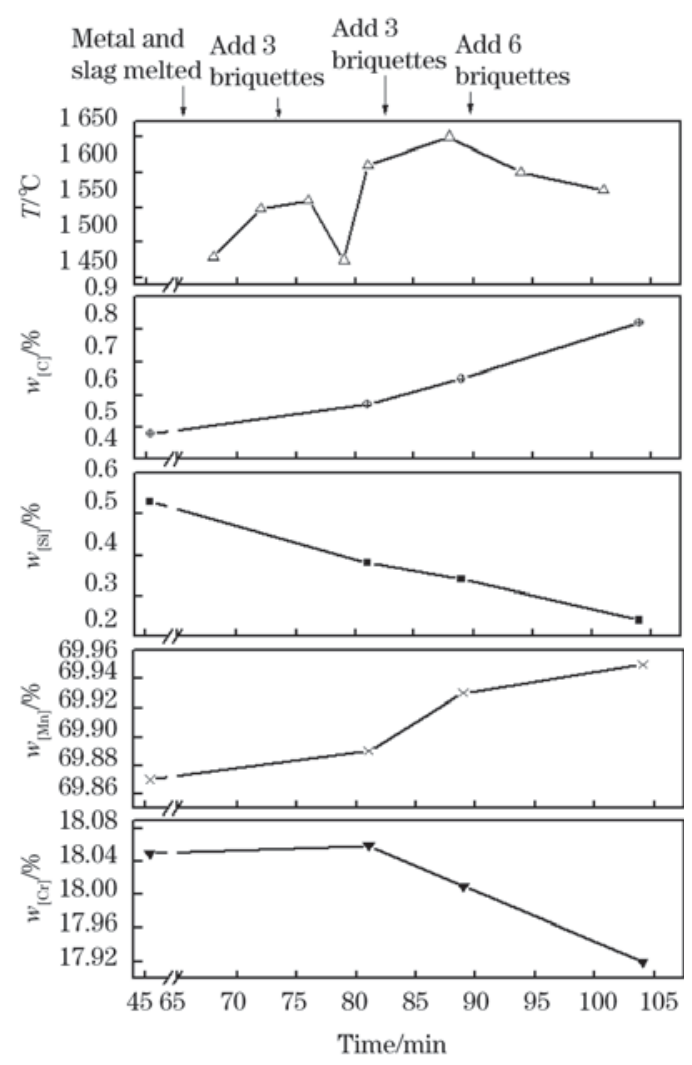

Fig. 4 Changes of metal temperature and compositions during test $\mathrm{P4}$ 
Following, closely, every addition of briquettes to the liquid slag, there was a noticeable increase of the carbon content due to dissolution of the briquette carbon in the metal. Iron content of the metal increased also with the additions, as well as $\mathrm{FeO}$ content in slag (Table 6). The iron oxides from the briquettes may be reduced partially by $\mathrm{Si}$ and $\mathrm{Cr}$ as contents of both $\mathrm{Si}$ and $\mathrm{Cr}$ in the metal decreased. It is obvious that the quick dissolution of the briquettes in the slag largely improved conditions for heat transfer and enhanced reaction rates. However, while released from the disintegrated briquettes, some of the carbon may get dissolved in liquid metal and some of the oxides may not react with carbon. Silicon with a higher affinity for oxygen than carbon will then react with the oxides, resulted in the [Si]-decrease shown in Fig. 4.

Results in Figs. 3 and 4 as well as in Table 6 also imply that the speed of briquette melting is much higher when the briquettes are brought into contact with liquid slag than with liquid metal.

Fig. 2 shows that with first heating and then melting of the briquettes together with the metal as in test P1, $80 \%$ of the oxides were reduced by carbon. The fluxing of the briquettes as in test P5 resulted in 56\% of reduction of the oxides carried out through $\mathrm{Si}$, as well as $47 \%$ loss of briquette carbon. The Si-reduction in test P4 was twice as large as that in test P1, but lower than that in test P5. This may be due to lower values of both [Si] in metal and mass of the briquettes charged to the slag in test P4 than these in test P5 (Table 3). A lower melt temperature for test P5, Table 5, favoured also the Si-reduction.

Charging cold briquettes on the surface of liquid slag with a quantity around $2.0 \%$ of the metal mass may also induce a heavy splashing of both the slag and dissolved briquettes on to the upper lining. The solidification of the materials may cause some operation problems, as well as a loss of recyclable metal. As seen in Table 6, contents of some of the oxides in the slag solidified on the wall are higher than the contents in the final slag for tests P4 and P5. Due to this loss, the increases of element mass in the metal in the two tests are lower than in test A-2, as seen in Fig. 2.

Higher values of metal mass increases in the tests of A-series than in the P-series indicate that the method of material charging of the A-series is more favourable for the smelt-reduction. An earlier fluxing of the briquettes by the neighbouring slag former made it possible to form small local zones of smelt-reduction near the furnace bottom. The carbon concentrations in these zones may be much higher than that in the bath formed after the meltdown, making the carbon reduction more favourable. The melt boiling in the zones may also be weak. The absence of silicon in these zones is necessary.

With briquettes sandwiched by the metal layers high in silicon content in test A-2, $87 \%$ of the oxides in the briquettes were reduced by $\mathrm{Si}$ and $47 \%$ of the briquette carbon was lost. A longer heating time with lower temperature, Table 7, may favour the Si-reduction and contribute to the carbon loss.

In test A-6 metal pieces with high $\mathrm{Si}$ content were also close to the briquettes, but the degree of carbon reduction was nearly $80 \%$. This high degree may be attributed to high carbon content in the zones as a result of a high briquette ratio. The melt temperature increased also faster in test A-6, being already $1669{ }^{\circ} \mathrm{C}$ after $57 \mathrm{~min}$ and thus, un-favourable for Si-reduction. In test A-10 the extent of both the Si-reduction and the loss of briquette carbon were rather low, attributable to the lower content of $\mathrm{C}$ and $\mathrm{Si}$ in the charged metal (Table 3).

\subsection{On internal EAF smelt-reduction of the waste- carbon briquettes}

There were $\mathrm{Cr}$ oxides of $7 \%-8 \%$ in the two types of briquettes smelted in the present study (Table 2). Chromium is an expensive and high-concentration (around 18\%) element in stainless steel ${ }^{[5]}$. It is therefore important, from both environmental and economic considerations, to recover the $\mathrm{Cr}$ in the waste oxides. Usually, chromium oxide in slag is reduced by silicon, a less expensive ele$\operatorname{ment}^{[2,5,6]}$.

A Si-reduction can lead to not only a risk of metal contamination $^{[2,5]}$, but also an increased environment impact. The direct impact is the generation of a large amount of slag, as the $\mathrm{SiO}_{2}$, the reduction product, must be neutralized using lime $\mathrm{e}^{[5,7]}$. Besides, the production of $\mathrm{FeSi}$ also generates a large amount of $\mathrm{CO}_{2} \mathrm{gas}^{[8]}$, which may be regarded as an indirect impact to environment induced by the Si-reduction.

On the other hand, carbon reduction hardly generates any slag, but only mixture of $\mathrm{CO}$ and $\mathrm{CO}_{2}$ gases ${ }^{[7-12]}$. Carbon materials are also much cheaper than silicon. These together make carbon as a reducing agent more environmentally and economically attractive than silicon. Carbon was then selected as the main reducing agent for recovery the metals from the waste briquettes ${ }^{[13-16]}$. However, literatures ${ }^{[2,5,7]}$ have shown some difficulties for maintaining favourably thermodynamic and kinetic conditions for carbon reduction of metal oxides in a production EAF. Some of the results from the present study agree rather well with the literature. 
For an EAF to carry out smelt-reduction of the briquettes with high rates of metal recovery achieved via carbon reduction, it is proposed, based on the results from the present study and the literature, to charge a layer of metal with low silicon content at the EAF bottom. Briquettes mixed with fluxing agent or slag former are charged on the bottom layer. The basicity of the slag former should not be much higher than one to favour an early slag melting. The silicon contained in the metal charge around the briquette layer should also be minimised. The briquette zone should be near the heat source of the furnace and under the level of the melt. The briquettes should be away from the furnace lining, too, in order to prevent their sintering on surfaces of the refractory material.

While charging after the meltdown, the mass of the briquettes for an addition should be less than $1 \%$ of the metal mass. The melt temperature may be kept high enough before and after the additions to facilitate carbon reduction. The Si-containing metal needed for the heat should be charged after or near to the end of the smeltreduction.

\section{Conclusions}

Briquettes containing carbon and wastes from the production of stainless steel have been tested by using an induction furnace to gain information useful for smeltreduction of the briquettes carried out by large scale EAF or induction furnace.

The briquettes were not disintegrated while being heated at $1186{ }^{\circ} \mathrm{C}$ under a load of $3.5 \mathrm{~kg}$. It was also possible to charge the briquettes with room temperature directly to the melt surface. The quantity of each charging should be less than $1 \%$ of the metal mass to avoid a heavy splashing.

The increase of element mass in metal and extent of carbon reduction of the oxides in the briquettes depend on the ways of material charging and melting. When the briquettes were neighboured with flux or slag former and sandwiched by layers of metal with low silicon content, higher rates of metal recovery via carbon reduction were obtained. The loss of briquette carbon was also lower. One of the reasons may be a formation of some small local zones of high carbon concentration, in which carbon reduction can be enhanced during the charger heating.

It is recommended, based on results from the present smelting tests and the literature, to mix the briquettes with slag former of low melting point and then charge the mixture on a layer of metal chargers with low silicon content. The briquette-slag layer should also be located near to the heat source and below the melt surface. The silicon, if needed, could be added to the melt at the completion of the smelt reduction.

This study was carried out within MiMeR at Luleå University of Technology (LTU), Sweden. The authors wish to thank all the MiMeR colleagues and members for their support and help to the work, especially Mr. Nils Holmberg and Dr. Nourreddine Menad.

During the time of research visits at LTU, Peng Xue, Dongfeng He and Jianli Li have been supported financially by Chinese Scholarship Council (CSC), and Center for Advanced Mining and Metallurgy (CAMM), at LTU, which is gratefully acknowledged.

\section{References:}

[1] J. X. Fu, G. H. Tang, R. J. Zhao, W. S. Hwang, J. Iron Steel Res. Int. 21 (2014) 275-281

[2] L. A. Neumeier, M. J. Adam, Trans. of the AFS 92 (1984) 749-756.

[3] R. J. Matway, N. L. Deferrari, R. L. Deszo, M. A. Gipko, S. E. Kwasny, in: 47th Electric Furnace Conference Proceedings, Electric Furnace Division of the Iron and Steel Society, Orlando, 1989, pp. 113-119.

[4] Q. X. Yang, Nils Holmberg, Bo Björkman, Steel Res. Int. 80 (2009) 422-428.

[5] S. Sun, P. Uguccioni, M. Bryant, M. Ackroyd, in: 55th Electric Furnace Conference Proceedings, Iron and Steel Society, Chicago, 1997, pp. 297-302.

[6] C. W. McCoy, F. C. Langenberg, JOM 16 (1964) 421-424.

[7] K. Gustafsson, R. Vikman, in: Proceedings of 4th European Electric Steel Congress, Madrid, Spain, 1992, pp. 51-60.

[8] G. C. Jiang, S. Q. Guo, X. B. Zhang, Y. Q. Zhang, K. D. Xu, J. Iron Steel Res. Int. 7 (2000) No. 2, 50-54.

[9] X. F. Hu, L. S. Ökvist, Q. X. Yang, B. Björkman, Ironmak. Steelmak. 42 (2015) 409-416.

[10] X. F. Hu, Q. X. Yang, L. S. Ökvist, B. Björkman, Steel Res. Int. 86 (2015) $1-9$.

[11] X. F. Hu, H. J. Wang, L. D. Teng, S. Seetharaman, Journal of Mining and Metallurgy, Section B: Metallurgy, 49 (2013) 207-215.

[12] R. S. Sampaio, M. E. Rezede, L. P. Almeida, in: 55th Electric Furnace Conference Proceedings, Iron and Steel Society, Chicago, 1997, pp. 281-287.

[13] D. Chakraborty, S. Ranganathan, S. N. Sinha, Metall. Mater. Trans. B 41 (2010) 10-18.

[14] D. Chakraborty, S. Ranganathan, S. N. Sinha, Metall. Mater. Trans. B 36 (2005) 437-444.

[15] G. Z. Ye, E. Burström, M. Kuhn, J. Piret, Scand. J. Metall. 32 (2003) 7-14.

[16] N. S. Sunder Murti, V. Seshadri, ISIJ 22 (1982) 925-933. 